\title{
Allelopathic potential of bark and leaves of Esenbeckia leiocarpa Engl. (Rutaceae)
}

\author{
Flaviana Maluf Souza ${ }^{1,4}$, Sergius Gandolfi ${ }^{2}$, Sonia Cristina Juliano Gualtieri de Andrade Perez ${ }^{3}$ e \\ Ricardo Ribeiro Rodrigues ${ }^{2}$
}

Recebido em 17/11/2008. Aceito em 22/07/2009

\begin{abstract}
Allelopathic potential of bark and leaves of Esenbeckia leiocarpa Engl. (Rutaceae)). We investigated the inhibitory potential of aqueous extracts of bark and leaves of Esenbeckia leiocarpa Engl. on lettuce germination and early seedling growth. We compared the effects of four concentrations $(100,75,50$ and $25 \%)$ of each extract to water and polyethylene glycol (PEG 6000) solution controls for four replicates of 50 seeds for germination and four replicates of ten seedlings for seedling growth. The inhibitory effects of E. leiocarpa extracts on the percentage of germination and on the germination speed seemed to be more than simply an osmotic effect, except for the percentage of seeds germinated in bark extracts. When compared to water control, both bark and leaf extracts delayed germination, and leaf extracts also affected the percentage of germinated seeds. Leaf extracts of all concentrations strongly inhibited the development of seedlings and caused them some degree of abnormality; bark extracts also caused abnormalities and reduced seedling growth. Root development was more sensitive to the extracts than hypocotyl growth. The negative effects of leaf extracts on germination and seedling growth were more pronounced than those of bark extracts, and the overall effects of both extracts were positively correlated with extract concentrations. Key words: allelopathy, germination, growth, inhibition, plant-plant interaction
\end{abstract}

RESUMO - (Potencial alelopático de folhas e cascas de Esenbeckia leiocarpa Engl. (Rutaceae)). Neste trabalho, nós investigamos o potencial inibitório de extratos aquosos de folhas e cascas de Esenbeckia leiocarpa Engl. na germinação e no crescimento inicial de plântulas de alface. Nós comparamos os efeitos de quarto concentrações (100, 75, 50 e 25\%) de cada extrato a um controle em água e outro em uma solução de polietilenoglicol (PEG 6000), com quatro repetições de 50 sementes para o experimento de germinação e quatro repetições de 10 plântulas para o experimento de crescimento. Os efeitos inibitórios dos extratos de E. leiocarpa na porcentagem e na velocidade de germinação foram mais do que um efeito do potencial osmótico das soluções, exceto para a porcentagem de sementes germinadas nos extratos de casca. Ambos os extratos causaram atrasos na germinação, sendo que os extratos de folha afetaram também a porcentagem de sementes germinadas. Os extratos de folha, em todas as concentrações, inibiram fortemente o desenvolvimento das plântulas e causaram a todas elas algum grau de anormalidade; os extratos de casca também causaram anormalidades e reduziram o crescimento das plântulas. O desenvolvimento da radícula foi mais sensível à ação dos extratos do que o crescimento do hipocótilo. Os efeitos negativos dos extratos de folhas foram mais pronunciados do que os causados pelos extratos de casca e os efeitos de ambos os extratos foram sempre positivamente correlacionados com sua concentração.

Palavras-chave: alelopatia, crescimento, germinação, inibição, interação planta-panta

\section{Introduction}

Tropical forests are known for their high diversity, and the countless interactions of all organisms with biotic and abiotic factors in these forests still make the understanding of the processes responsible for community organization a complex and intriguing subject.

Among the factors that determine community structure and dynamics are the positive and negative plant-plant interactions (Callaway \& Walker 1997; Lortie et al. 2004; Michalet et al. 2006). One of the several ways by which plants can interact is through the release of secondary metabolites in the environment, which may cause direct or indirect interference of one plant on another, by a process called allelopathy (Rice 1984). Although most commonly reported as having a negative effect, the allelopathic process can also result in benefits to the organism that receives the allelochemical (e.g., Parvez et al. 2004; Orr et al. 2005; Dorning \& Cipollini 2006).

In plants, allelopathy is often related to harmful effects on germination and seedling growth (Kato-Noguchi 2003; Oliveira et al. 2004; Herranz et al. 2006; Cavieres et al. 2007;
Zhang et al. 2007). Some authors suggest that allelopathic effects can also contribute to promote shifts in density, dominance and spatial patterns of plant populations (Rice 1984; Wardle et al. 1998; Chou 1999; Ridenour \& Callaway 2001). Thus, allelopathic plants may have a differential role in species coexistence (Inderjit \& Callaway 2003) and in forest succession (Peng et al. 2004). Despite its importance, allelopathy is a poorly studied mechanism among tropical tree species, and the relevance of this process has probably been underestimated in the theories about the driving forces of ecological processes in tropical forests.

Evidence of allelopathy can be obtained by observing spatial patterns in the field (Inderjit \& Callaway 2003). In some cases, there are zones of growth inhibition beneath or around the canopy of an allelopathic plant, where individuals or species are suppressed (see examples in Rice 1984, Wardle et al. 1998; Inderjit \& Callaway 2003). Moreover, the changes in the environment and in the neighbouring vegetation caused by an allelopathic plant can favour the establishment of conspecifics (Wardle et al. 1998).

Esenbeckia leiocarpa Engl. is a tropical tree species that occurs in Seasonal Semideciduous Forests. It is a

\footnotetext{
1 Universidade Estadual de Campinas, Instituto de Biologia, Departamento de Botânica, Campinas, SP, Brasil

2 Universidade de São Paulo, Escola Superior de Agricultura “Luiz de Queiroz”, Departamento de Ciências Biológicas, Piracicaba, SP, Brasil

3 Universidade Federal de São Carlos, Departamento de Botânica, São Carlos, SP, Brasil

4 Autor para correspondência: flavianams@yahoo.com.br
} 
deciduous and autochorous tree (Morellato 1991) and reaches up to $18 \mathrm{~m}$ in height (Pirani \& Skorupa 2002). In addition to the fact that this species is frequently found in clusters (Seoane et al. 2000), adult individuals (diameter at breast height - $\mathrm{DBH} \geq 4.8 \mathrm{~cm}$ ) of E. leiocarpa were found to be more abundant under the canopies of individuals of E. leiocarpa than under eight other canopy species (F. M. Souza et al., unpublished data). These data suggest that $E$. leiocarpa may inhibit other plant species or facilitate the establishment of their own individuals. The presence of compounds with allelopathic potential in roots and leaves of this species (Delle Monache et al. 1989; Delle Monache et al. 1990; Nakatsu et al. 1990; Michael 1993), as well as the existence of phytotoxic substances in another species of the genus Esenbeckia (Mata et al. 1998) strengthen the idea that $E$. leiocarpa may be allelopathic.

In this study, we carried out laboratory experiments to investigate the effects of aqueous extracts of bark and leaves of E. leiocarpa on seed germination and early seedling growth of the test-plant Lactuca sativa L. as evidence of allelopathy. Despite the known limitations of laboratory experiments to show the occurrence of allelopathy under natural conditions (Stowe 1979; Inderjit \& Callaway 2003), they are very useful as an initial investigation of allelopathy, in addition to having the advantages of low cost, rapid execution and easy replication (Leather \& Einhellig 1986; Weidenhamer et al. 1989; Inderjit \& Weston 2000). We also discuss the ecological implications of the results for the vegetation patterning of Tropical Seasonal Semideciduous Forests.

\section{Material and methods}

Aqueous extracts - At the beginning of the rainy season (November 2004), we collected mature healthy leaves and bark of ten individuals of Esenbeckia leiocarpa at Caetetus Ecological Station, a Seasonal Semideciduous Forest Reserve located in Central Western São Paulo state, Brazil $\left(22^{\circ} 41^{\prime} \mathrm{S} ; 49^{\circ} 10^{\prime} \mathrm{W}\right)$. The collected material was frozen in a domestic refrigerator $\left(-10^{\circ} \mathrm{C}\right)$ until use.

The collected material was dried in an oven at $80^{\circ} \mathrm{C}$ until reaching a constant weight and then ground in a blender in a proportion of $7.1 \%(\mathrm{w} / \mathrm{v})$ for each material ( $50 \mathrm{~g}$ of dried leaves in $700 \mathrm{~mL}$ of distilled water and 15 $\mathrm{g}$ of dried bark in $210 \mathrm{~mL}$ of distilled water). After that, the extracts were centrifuged for three minutes, collected by decantation and then vacuumfiltered through one layer of filter paper to obtain the most concentrated extract $(100 \%)$ of each material. We diluted these solutions in distilled water to achieve $75(\sim 5.3 \% \mathrm{w} / \mathrm{v}), 50(\sim 3.5 \% \mathrm{w} / \mathrm{v})$ and $25 \%(\sim 1.8 \% \mathrm{w} / \mathrm{v})$ concentrations and stored the extracts at $-10^{\circ} \mathrm{C}$ until use.

Germination - We evenly placed 50 seeds of lettuce (Lactuca sativa L. var. Grand Rapids) in $9 \mathrm{~cm}$-diameter Petri dishes lined with two layers of previously autoclaved filter paper and moistened with $5 \mathrm{~mL}$ of each extract $(\mathrm{n}=$ four replicates). We then placed the Petri-dishes in a chamber with an exhaust fan for five hours and remoistened them with $5 \mathrm{~mL}$ of distilled water.

As controls, we used distilled water and a Polyethylene glycol 6000 (PEG 6000) solution. This procedure was carried out to assess the influence of the osmotic potential of the extracts on seed germination. The osmotic potential of the most concentrated (100\%) extract of each material was first measured using a FISKE OS Osmometer, with samples of $250 \mu \mathrm{L}$ of each extract previously defrosted at room temperature (bark extract $=-0.06 \mathrm{MPa}$; leaf extract $=-0.31 \mathrm{MPa}$ ). The recommended amount of PEG (Villela et al. 1991) was then diluted in distilled water and shaken for 24 hours to obtain PEG solutions with the same osmotic potential of each $100 \%$ extract. The
Petri dishes were sealed with parafilm and placed randomly in a growth chamber (FANEM 347) in the dark at $26-28^{\circ} \mathrm{C}$. The germinated seeds $(2$ $\mathrm{mm}$ of radicle protrusion) were counted and removed every 12 hours up to the seventh day and the percentage of germination and germination speed were calculated according to the formulae presented by Labouriau (1983). Growth - Lettuce seeds of 4-6 mm radicle length that had been previously germinated for 27 hours in distilled water (germination procedures were the same as those described in the previous item, except for the 12-hour photoperiod) were transferred to plastic boxes lined with two layers of filter paper. Ten germinated seeds were evenly distributed in each box (n = four replicates), and the filter paper was moistened with $12 \mathrm{~mL}$ of each extract or distilled water as a control. The plastic boxes were sealed with transparent thick plastic bags with sparse holes and placed randomly in a growth chamber (FANEM 347) at $26-28^{\circ} \mathrm{C}$ under a 12 -hour photoperiod. After seven days, the seedlings were classified as normal or abnormal, according to Brasil (1992), and the hypocotyls and the roots of the normal seedlings were measured with a digital caliper.

Data analysis - The percentage of germination and the germination speed of bark and leaf $100 \%$ extracts were compared to their equivalent PEG solutions with a t test, assuming unequal variances. In cases of significant results, an analysis of variance (ANOVA) was used followed by a Tukey test to look for differences among all treatments (the four concentrations of bark and leaf extracts and water control). This analysis was also performed to compare the proportion of abnormal seedlings among treatments. Differences in the root and hypocotyl length of normal seedlings were analysed by a Kruskal-Wallis test, followed by the Dunn test for multiple comparisons, since the variances of those variables were not homogeneous (Zar 1999). When the variables presented only one observation, the single value was compared to the $95 \%$ confidence interval for the mean of the control. Linear regression was used to evaluate the dependence of each variable (percentage of germination, germination speed, hypocotyl and root length) on the concentration of the extracts. Statistical tests were performed with $5 \%$ of significance.

All the proportions were transformed using a slight modification of the Freeman and Tukey transformation, since it provides better results for small and large proportions than the most commonly used formulae (Zar 1999).

\section{Results}

Germination -The lettuce seeds germinated slower in the $100 \%$ bark extract than in the equivalent PEG solution $(t=$ - 5.02; d.f. $=3.58 ; \mathrm{p}=0.01 ;$ Tab. 1). Since the percentage of germinated seeds did not differ between this extract and the $\operatorname{PEG}(t=-1.33$; d.f. $=4.98 ; \mathrm{p}=0.24$; Tab. 1$)$, this variable was not compared among the four concentrations and the water control. The germination of the seeds in the $100 \%$ leaf extract was close to zero, with only two seeds germinated in one of the replicates, differing from the equivalent PEG solution $(t=$ -11.71 ; d.f. $=3.80 ; \mathrm{p}<0.001$; Tab. 1$)$. The germination speed in this single replicate $\left(0.18\right.$ days $\left.^{-1}\right)$ was outside the confidence limit of the PEG solution (lower limit $=0.63$ and upper limit $=0.92$ days $\left.^{-1}\right)$, indicating that the germination speed in the bark extract was lower than in the PEG solution, allowing the continuation of the subsequent analysis.

The number of germinated seeds in the leaf extracts was lower than those in the water control $(\mathrm{F}=153.58$; d.f. $=4$; $\mathrm{p}<0.001$; Fig. 1) and inversely proportional to the extract concentrations $\left(R^{2}=0.98\right.$; d.f. $=18 ; p<0.001 ;$ Fig. 1$)$. The germination speeds of the seeds in the 75,50 and $25 \%$ leaf extracts and in the 100 and $75 \%$ bark extracts were lower than those observed in the water control $(\mathrm{F}=87.50$; d.f. $=7$; $\mathrm{p}<0.001$; Fig. 2); the value recorded in the $100 \%$ leaf extract $\left(0.18\right.$ days $\left.^{-1}\right)$ was lower than the lower limits of the confidence 
Table 1. Percentage and germination speed of lettuce (Lactuca sativa L.) seeds in the most concentrated $(100 \%)$ aqueous extracts of Esenbeckia leiocarpa Engl. barks and leaves and in the PEG (polyethylene glycol 6000) solutions with osmotic potential equivalent to the extracts (mean $\pm \mathrm{SE}$ ).

\begin{tabular}{lll}
\hline \multicolumn{1}{c}{ Treatment } & \multicolumn{1}{c}{ Germination $(\%)$} & \multicolumn{1}{c}{ Germination speed (days $\left.{ }^{-1}\right)$} \\
\hline Leaf $100 \%$ & $0.5 \pm 0.5^{\mathrm{a}}$ & $0.18^{\mathrm{a}}$ \\
PEG $(-0.28 \mathrm{MPa})$ & $65.0 \pm 6.6^{\mathrm{b}}$ & $0.78 \pm 0.05^{\mathrm{b}}$ \\
\hline Bark $100 \%$ & $75.5 \pm 4.6^{\mathrm{a}}$ & $0.65 \pm 0.01^{\mathrm{a}}$ \\
PEG $(-0.12 \mathrm{MPa})$ & $85.0 \pm 6.1^{\mathrm{a}}$ & $0.86 \pm 0.04^{\mathrm{b}}$ \\
\hline
\end{tabular}

Different superscript letters within each column indicate that the means were significantly different $(\mathrm{p}<0.05)$ between the extract and its corresponding PEG solution

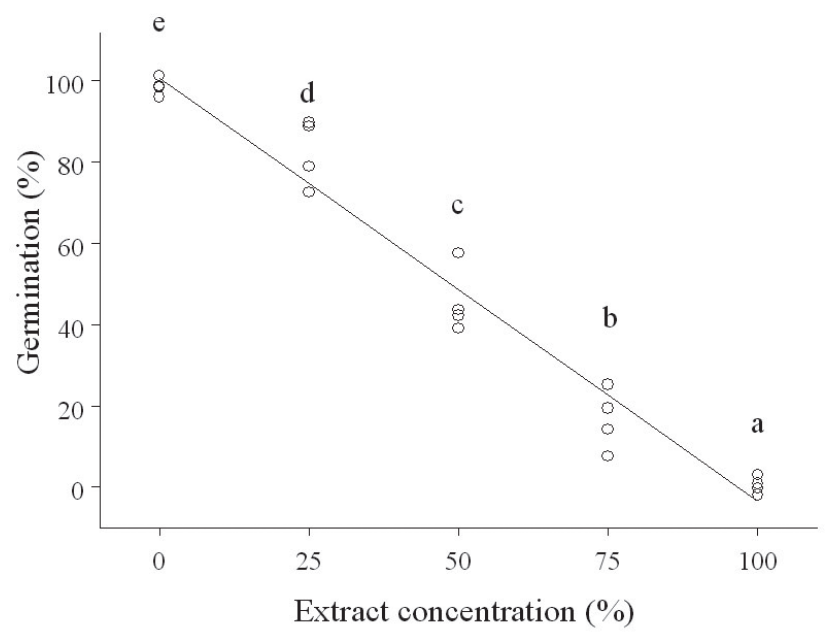

Figure 1. Percentage of germination of lettuce (Lactuca sativa L.) seeds in different concentrations of leaf aqueous extracts of Esenbeckia leiocarpa Engl. $\left(0=\right.$ water control; $\left.\mathrm{R}^{2}=0.98 ; \mathrm{p}<0.001\right)$. Different letters indicate significant differences among concentrations by Tukey test $(\mathrm{p}<0.05)$.

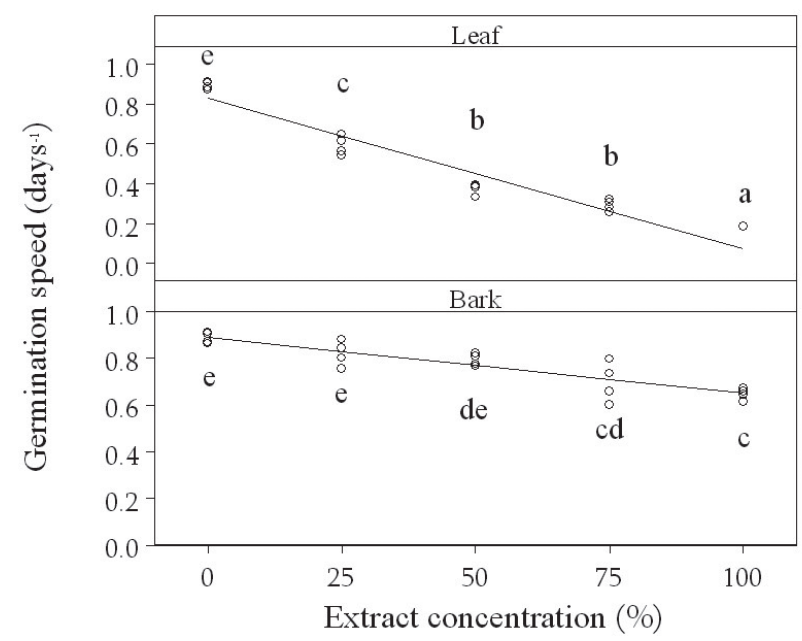

Figure 2. Germination speed of Lactuca sativa L. seeds in different concentrations of aqueous extracts of bark and leaves of Esenbeckia leiocarpa Engl. ( $0=$ water control; bark: $\mathrm{R}^{2}=0.78 ; \mathrm{p}<0.001$; leaf: $\mathrm{R}^{2}=0.93$; $\left.\mathrm{p}<0.001\right)$. Different letters indicate significant differences among treatments $(\mathrm{p}<0.05)$. intervals of all other treatments (leaf $75 \%=0.25$; leaf $50 \%=$ 0.34 ; leaf $25 \%=0.51$; bark $100 \%=0.61$; bark $75 \%=0.57$; bark $50 \%=0.75$; bark $25 \%=0.73$; water control $=0.87$ ). The germination speed was also inversely proportional to both leaf $\left(\mathrm{R}^{2}=0.93\right.$; d.f. $=15 ; \mathrm{p}<0.001$; Fig. 2$)$ and bark $\left(\mathrm{R}^{2}=0.78\right.$; d.f. $=18 ; \mathrm{p}<0.001 ;$ Fig. 2) extract concentrations.

The reduction in the percentage of germination and in the germination speed ranged from approximately $15 \%$ (25\% leaf extract) to almost $100 \%$ (100\% leaf extract), and from approximately $20 \%$ (75\% bark extract) to $80 \%$ (100\% leaf extract), respectively. The leaf extracts affected the germination speed more than the bark extracts in all concentrations (Fig. 2). The differences between the materials were more pronounced between the $100 \%$ extracts and diminished as the concentration decreased (Fig. 2).

Growth - Both leaf and bark extracts induced the occurrence of abnormalities in the seedlings. The most frequent problems were the weak development and the disproportion between the root and the hypocotyl. In most cases, roots were more damaged than the aerial part of the seedlings. In the former, the most common abnormalities were the oxidation of the cap, longitudinal cracks and negative geotropism (Fig. 3); in the latter, the most common problems were twists and small cotyledonary necrosis (Fig. 3).

All of the seedlings grown in the leaf extracts showed some degree of abnormality. The proportion of abnormal seedlings grown in the leaf extracts was significantly higher than in the control for all concentrations, whereas only the proportion of abnormal seedlings grown in the 100 and $75 \%$ bark extracts were higher than in the control $(\mathrm{F}=15.38$; d.f. $=8 ; p<0.001 ;$ Tab. 2). The proportion of abnormal seedlings grown in the bark extracts was positively related to the concentration $\left(\mathrm{R}^{2}=0.77\right.$; d.f. $=17 ; \mathrm{p}<0.001$; Tab. 2$)$.

Since all of the seedlings grown in the leaf extracts were abnormal, we analysed the root and hypocotyl length of the seedlings grown only in bark extracts. In the $100 \%$ extract, only one out of the 40 seedlings was normal. The root length of this single seedling $(10.9 \mathrm{~mm})$ was comprised of the confidence limits of the $75 \%$ bark extract (lower limit $=9.3$; upper limit $=16.6$ ), but was lower than the lower limit of the confidence interval of all the other treatments $(50 \%$ bark $=16.2 ; 25 \%$ bark $=27.3$; water $=40.9)$. The hypocotyl length of this seedling $(3.6$ $\mathrm{mm}$ ) was lower than the lower limit of the confidence interval of all the other concentrations and the water control $(75 \%$ bark $=4.1 ; 50 \%$ bark $=7.4 ; 25 \%$ bark $=7.1$; water $=8.2$ ).

The root length of the normal seedlings grown in other concentrations also differed from the control (Kruskal-Wallis $\mathrm{H}=85.48$; d.f. $=3 ; \mathrm{p}<0.001$; Tab. 2) and was inversely proportional to the extract concentration $\left(\mathrm{R}^{2}=0.69\right.$; d.f. $=111$; $\mathrm{p}<0.001$; Tab. 2; Fig. 4). Mean root length was reduced by at least 34\% (in the slightest concentrated extract) and by up to $75 \%$ (in the $100 \%$ extract). Hypocotyls of seedlings grown in $75 \%$ extracts differed from the control (Kruskal-Wallis $\mathrm{H}$ $=13.87$; d.f. $=3 ; \mathrm{p}=0.003$; Tab. 2 ; Fig. 4); the reduction in mean hypocotyl length ranged from $40 \%$ (in the $75 \%$ ) to $59 \%$ (in the $100 \%$ extract). 
Table 2. Percentage of abnormal seedlings, root length and hypocotyl length of normal seedlings of lettuce (Lactuca sativa L.) grown in aqueous extracts of barks of Esenbeckia leiocarpa Engl. (mean \pm SE; concentration " 0 " = water control).

\begin{tabular}{clll}
\hline Extract concentration (\%) & \multicolumn{1}{c}{ Abnormal seedlings (\%) } & \multicolumn{1}{c}{ Root length (mm) } & Hypocotyl length (mm) \\
\hline 100 & $96.7 \pm 3.3^{\mathrm{b}}$ & $10.9^{\mathrm{a}}$ & $3.6^{\mathrm{a}}$ \\
75 & $82.5 \pm 8.5^{\mathrm{b}}$ & $12.9 \pm 1.5^{\mathrm{ab}}$ & $5.4 \pm 0.5^{\mathrm{b}}$ \\
50 & $32.5 \pm 22.9^{\mathrm{a}}$ & $17.0^{\mathrm{b}} \pm 0.4^{\mathrm{b}}$ & $8.2 \pm 0.4^{\mathrm{c}}$ \\
25 & $5.0 \pm 2.9^{\mathrm{a}}$ & $29.3 \pm 1.0^{\mathrm{c}}$ & $8.1 \pm 0.5^{\mathrm{c}}$ \\
0 & $0^{\mathrm{a}}$ & $44.3^{\mathrm{a}}$ & $8.8^{\mathrm{d}} \pm 0.3^{\mathrm{c}}$ \\
\hline
\end{tabular}

Different superscript letters within each column indicate that the means were significantly different $(\mathrm{p}<0.05)$ among extract concentrations.
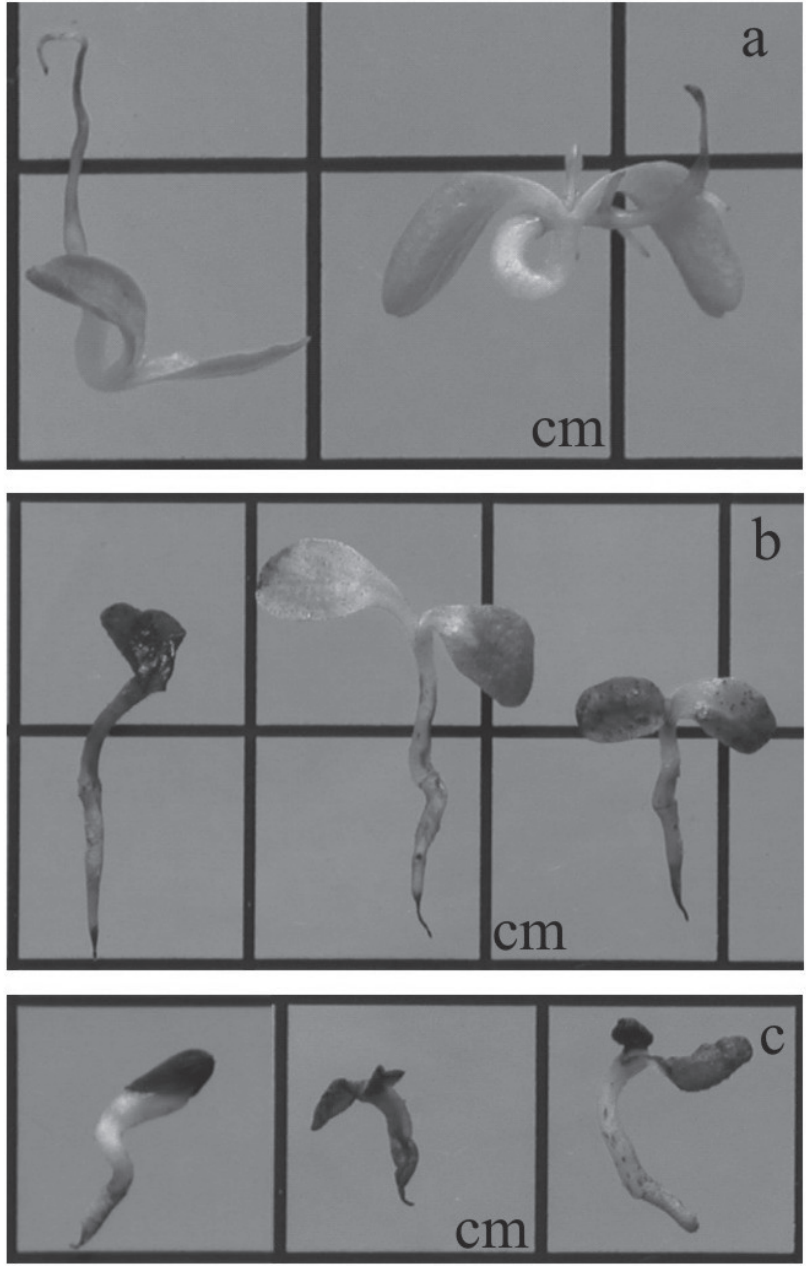

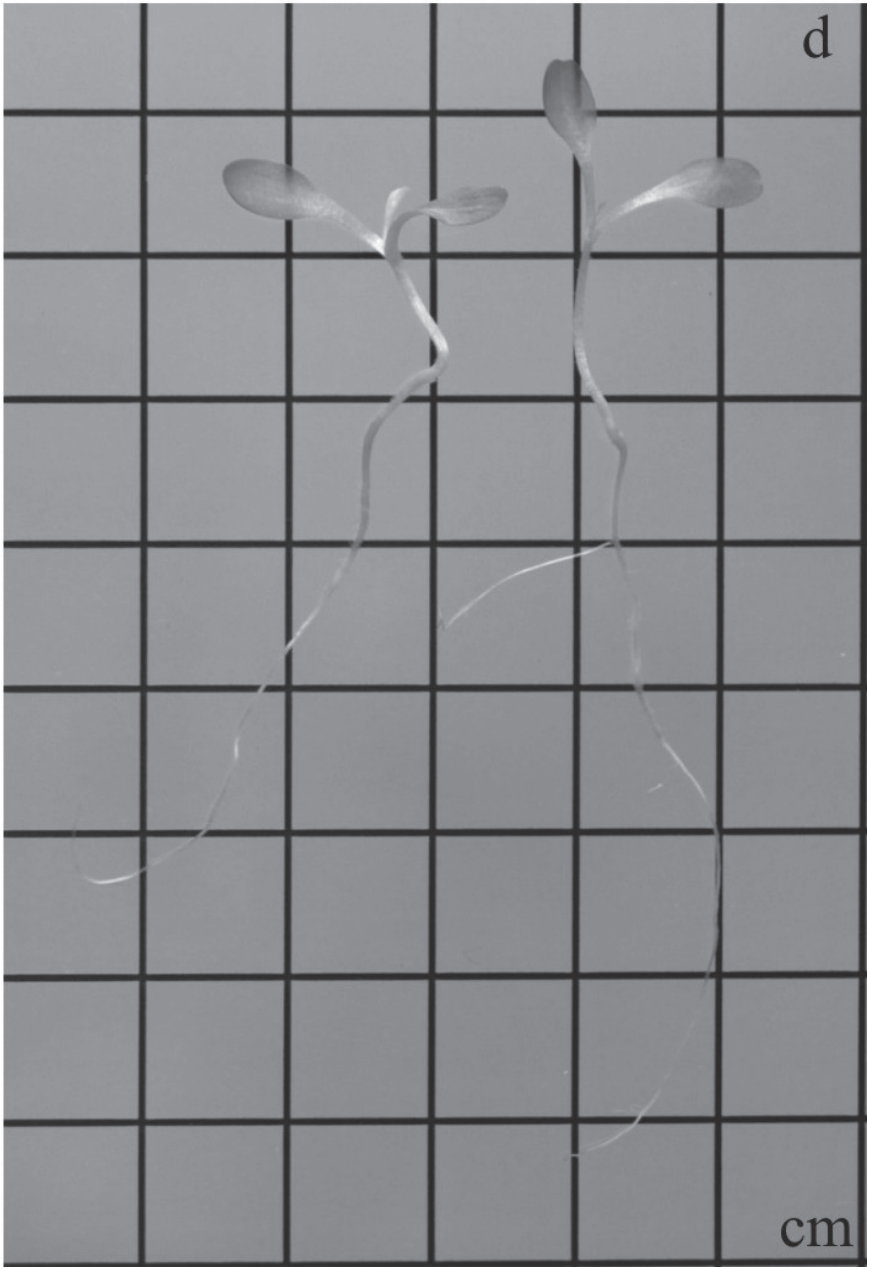

$\mathrm{cm}$

Figure 3. Abnormalities of Lactuca sativa L. seedlings grown in aqueous extracts of bark and leaves of Esenbeckia leiocarpa Engl. - (a) negative geotropism and twisted hypocotyl (75\% bark extract); (b) cotyledonary necrosis, root longitudinal cracks and oxidation of the root cap (75\% leaf extract); (c) rottenness and weak development (100\% leaf extract); (d) normal seedlings (water control).

\section{Discussion}

The differences in the percentages of germination and germination speed between the $100 \%$ leaf extract and PEG 6000 suggest that the inhibition of germination was not only an effect of the osmotic potential. The same can be said for the germination speed in the bark extract, but not for the percentage of germination, in which the reduction seems to be exclusively an osmotic effect.
Both leaf and bark extracts were phytotoxic and potentially inhibitors of seed germination, they also induced abnormalities in seedling structures and reduced the growth of normal seedlings. The germination was delayed rather than reduced; seedling development was more sensitive to the extracts than germination, and root elongation was even more affected than that of the hypocotyl. In general, the negative effects increased with the concentration of the extracts. This pattern of 


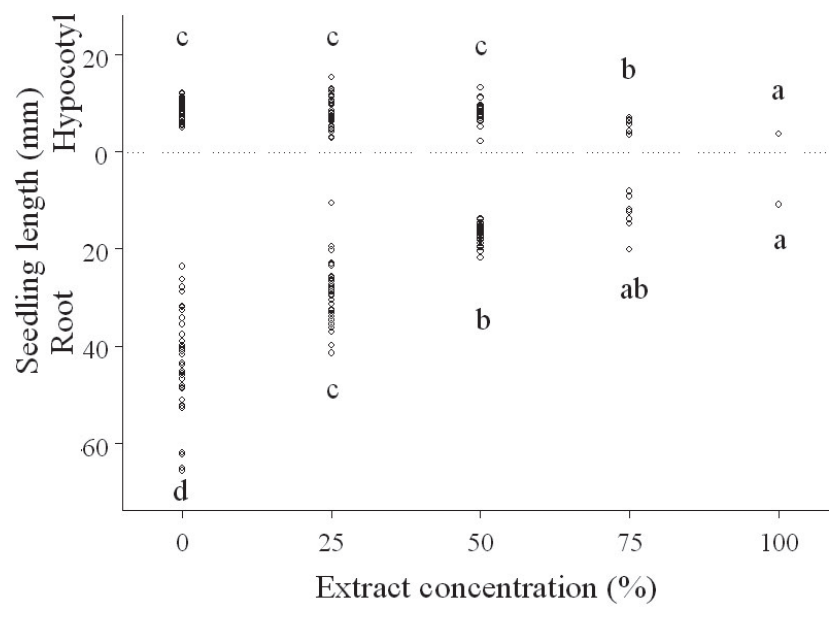

Figure 4. Root and hypocotyl length of normal seedlings of Lactuca sativa L. grown in aqueous extracts of bark of Esenbeckia leiocarpa Engl. ( 0 = water control; $\left.\mathrm{R}^{2}=0.69 ; \mathrm{p}<0.001\right)$. Different letters within each seedling structure indicate that the means differed significantly among concentrations.

negative effects (effects on speed $>$ percentage; growth $>$ germination; radicle $>$ hypocotyl) is the same as those reported by several studies concerning other plant species around the world (e.g., Kato-Nogushi 2003, Dorning \& Cipollini 2006; Zhang et al. 2007).

Leaf extracts affected both germination and seedling development more strongly than bark extracts and caused damage that seemed severe enough to prevent seedling establishment, even at the lowest concentrations. Injuries resulting from bark extracts were less intense and occurred mostly at the highest concentrations. However, the hypothesis that the reduction of root growth caused by the bark extracts may also be sufficient to hinder the future seedling development should not be dismissed.

Studies regarding the consequences of alterations in germination process on the performance of individuals in natural forests are still lacking, which limits our discussion about the ecological implications of our findings. We hypothesize that the slow seed germination and the low germinability could affect the uptake of vital resources, such as light, water and nutrients. Similarly, root and shoot damages could probably delay or even prevent seedling development, which in turn would increase seedling vulnerability and competitive ability, decreasing the chances of a seedling to survive, grow and reach maturity.

However, to confirm the occurrence of the allelopathic activity, it is necessary to verify whether, in natural conditions, the compounds are released and accumulated in the environment at levels which could actually affect the individuals of the community (Putnam \& Tang 1986; Inderjit \& Callaway 2003). This stresses the importance of field experiments for the understanding of how, and to what extent, an allelopathic species may affect the community (Harborne 1997; Inderjit \& Weston 2000). On the other hand, in field conditions, it is almost impossible to isolate the allelopathic interference from the myriad of factors that are part of forest dynamics, such as competition or the activity of herbivores and pathogens (Putnam \& Tang 1986; Inderjit \& Del Moral 1997; Wardle et al. 1998).

Many factors can influence the allelopathic activity from the donor perspective, as well as influence the response of the receptor organism. The concentration of the compounds, for instance, may vary along the day and season, or may be influenced by environmental conditions (light, water, temperature and nutrients), genetic factors or even by the age of the plant or the organ (Rice 1984; Larcher 1995). Herbivores, pathogens and microorganisms can also increase or reduce the concentration of the allelochemicals (Rice 1984). In addition, the magnitude of the allelopathic effect may be species-specific and may vary according to the density of individuals receiving the compounds (Weidenhamer et al. 1989; Orr et al. 2005).

For E. leiocarpa, leaf age and season are factors particularly relevant for consideration in future studies, since this is a deciduous species. Taking this into account, it is necessary to ascertain whether the results observed for adult leaves are the same for recently fallen and for senescent leaves, and whether they vary with the season, since the leaves fall most abundantly during the drought period (Morellato 1991). Experiments to investigate the effects of E. leiocarpa on seeds of native species, as well as the production of stimulatory effects on its own seeds are essential to provide stronger evidence of an allelopathic potential and to better understand the role of this species in structuring plant communities.

Substances broadly recognized for their allelopathic potential, such as alkaloids and coumarins (Rice 1984; Michael 1993; Larcher 1995) were already reported as components of E. leiocarpa leaves (Delle Monache et al.1989; Delle Monache et al.1990; Nakatsu et al. 1990; Michael 1993). Although the constitution of the bark of $E$. leiocarpa is not known, substances of the same group were found in bark of another two Esenbeckia species (Oliveira et al. 1996), which suggests the presence of these compounds in the E. leiocarpa bark.

Although our data do not provide conclusive information about the allelopathic effects of E. leiocarpa bark and leaves, they showed the potential of this species to delay seed germination and strongly inhibit the seedling growth of lettuce seedlings. Whether or not this event occurs under natural conditions still remains to be investigated, but if the effects of E. leiocarpa on germination and growth of native species are similar to those reported here, this species may have an important role in the community organization and diversity of Tropical Seasonal Semideciduous Forests.

\section{Acknowledgements}

We would like to thank Dr. Ivany Válio and Dr. Carlos Alfredo Joly for the use of the Plant Physiology and the Ecophysiology laboratories, 
respectively. We are also grateful to Dulcinéia Pereira de Souza and Ana Lúcia Moreira for helping with laboratory procedures. This study was supported by grants from FAPESP (1999/09635-0) and from Brazilian National Research Council - CNPq (140555/2001-3).

\section{References}

Brasil. 1992. Regras para a análise de sementes. Brasília, Ministério da Agricultura e Reforma Agrária, SNDA, DNDV, CLV.

Callaway, R.M. \& Walker, L.R. 1997. Competition and facilitation: a synthetic approach to interactions in plant communities. Ecology 78: 1958-1965.

Cavieres, L.A.; Chacón, P.; Peñaloza, A.; Molina-Montenegro, M. \& Arroyo, M.T.K. 2007. Leaf litter of Kageneckia angustifolia D. Don (Rosaceae) inhibits seed germination in sclerophyllous montane woodlands of central Chile. Plant Ecology 190: 13-22.

Chou, C.H. 1999. Roles of allelopathy in plant biodiversity and sustainable agriculture. Critical Reviews in Plant Sciences 18: 609-636.

Delle Monache, F.; Benedetto, R.; Souza, M.A.M. \& Sandor, P. 1990. Esenbeckia leiocarpa: IIa. Further components. Gazzetta Chimica Italiana 120: 387-389.

Delle Monache, F.; Delle Monache, G.; Souza, M.A.M.; Cavalcanti, M.S. \& Chiappeta, A. 1989. Isopentenylindole derivatives and other components of Esenbeckia leiocarpa. Gazzetta Chimica Italiana 119: 435-439.

Dorning, M. \& Cipollini, D. 2006. Leaf and root extracts of the invasive shrub, Lonicera maackii, inhibit seed germination of three herbs with no autotoxic effects. Plant Ecology 184: 287-296.

Harborne, J.B. 1997. Plant Secondary Metabolism. Pp. 132-155. In: Crawley, M.J. (ed.). Plant Ecology, 2nd edn. Oxford, Blackwell Science Ltd.

Herranz, J.M.; Ferrandis, P.; Copete, M.A.; Duro, E.M. \& Zalacaín, A. 2006. Effect of allelopathic compounds produced by Cistus ladanifer on germination of 20 Mediterranean taxa. Plant Ecology 184: 259-272.

Inderjit \& Callaway, R.M. 2003. Experimental designs for the study of allelopathy. Plant and Soil 256: 1-11.

Inderjit \& Del Moral, R. 1997. Is separating resource competition from allelopathy realistic? The Botanical Review 63: 221-230.

Inderjit \& Weston, L.A. 2000. Are laboratory bioassays for allelopathy suitable for prediction of field responses? Journal of Chemical Ecology 26: 2111-2118.

Kato-Noguchi, H. 2003. Allelopathic potential of Pueraria thunbergiana. Biologia Plantarum 47: 471-473.

Labouriau, L.G. 1983. A germinaçăo das sementes. Washington, OEA.

Larcher, W. 1995. Physiological Plant Ecology. Berlin, Springer-Verlag.

Leather, G.R. \& Einhellig, F.A. 1986. Bioassays in the study of allelopathy. Pp. 133-145. In: Putnam, A.R. \& Tang, C.S. (eds.). The science of allelopathy. New York, John Wiley \& Sons.

Lortie, C.J.; Brooker, R.W.; Choler, P.; Kikvidze, Z.; Michalet, R.; Pugnaire, F.I. \& Callaway, R.M. 2004. Rethinking plant community theory. Oikos 107: 433-438.

Mata, R.; Macías, M.L.; Rojas, I.S.; Lotina-Hennsen, B.; Toscano, R.A. \& Anaya, A.L. 1998. Phytotoxic compounds from Esenbeckia yaxhoob. Phytochemistry 49: 441-449.
Michael, J.P. 1993. Quinoline, Quinazoline, and Acridone Alkaloids. Natural Product Reports 10: 99-108.

Michalet, R.; Brooker, R.W.; Lohengrin, A.; Cavieres, L.A.; Kikvidze, Z.; Lortie, C.J.; Pugnaire, F.I.; Valiente-Banuet, A. \& Callaway, R.M. 2006. Do biotic interactions shape both sides of the humped-back model of species richness in plant communities? Ecology Letters 9: 767-773.

Morellato, L.P.C. 1991. Estudo da fenologia de árvores, arbustos e lianas de uma floresta semidecídua no sudeste do Brasil (Campinas, SP). PhD. Thesis, Campinas State University.

Nakatsu,, T.; Johns, T. \& Kubo I. 1990. Isolation, structure and synthesis of novel 4 quinolinone alkaloids from Esenbeckia leiocarpa. Journal of Natural Products 53: 1508-1513.

Oliveira, F.M.; Sant'ana, A.E.G.; Conserva, L.M.; Maia, J.G.S. \& Guilhon, G.M.P. 1996. Alkaloids and coumarins from Esenbeckia species. Phytochemistry 41: 647-649.

Oliveira, S.C.C.; Ferreira, A.G. \& Borghetti, F. 2004. Effect of Solanum lycocarpum fruit extract on sesame seed germination and seedling growth. Allelopathy Journal 13(2): 201-210.

Orr, S.P.; Rudgers, J.A. \& Clay, K. 2005. Invasive plants can inhibit native tree seedlings: testing potential allelopathic mechanisms. Plant Ecology 181: 153-165.

Parvez, S.S.; Parvez, M.M.; Fujii, Y. \& Gemma, H. 2004. Differential allelopathic expression of bark and seed of Tamarindus indica L. Plant Growth Regulation 42: 245-252.

Peng, S.L.; Chen, Z.Q.; Wen, J. \& Shao, H. 2004. Is allelopathy a driving force in forest succession? Allelopathy Journal 14: 197-204.

Pirani, J.R. \& Skorupa, L.A. 2002. Rutaceae. Pp. 281. In: Wanderley, M.G.L; Shepherd, G.J. \& Giulietti, A.M. (coords.). Flora Fanerogâmica do Estado de São Paulo, vol 2. São Paulo, FAPESP-HUCITEC.

Putnam, A.R. \& Tang, C.S. 1986. Allelopathy: State of the Science. Pp. 1-19. In: Putnam, A.R. \& Tang, C.S. (eds.). The science of allelopathy. New York, John Wiley \& Sons.

Rice, E.L. 1984. Allelopathy. Orlando, Academic Press.

Ridenour, W.M. \& Callaway, R.M. 2001. The relative importance of allelopathy in interference: the effects of an invasive weed on a native bunchgrass. Oecologia 126: 444-450

Seoane, C.E.S.; Kageyama, P.Y. \& Sebben, A.M. 2000. Efeitos da fragmentação florestal na estrutura genética de populaçőes de Esenbeckia leiocarpa Engl. (Guarantã). Scientia Forestalis 57: 123-39.

Stowe, L.G. 1979. Allelopathy and its influence on the distribution of plants in an Illinois old-field. Journal of Ecology 67: 1065-1085.

Villela, F.A.; Doni Filho, L. \& Sequeira, E.L. 1991. Tabela de potencial osmótico em função da concentração de polietileno glicol 6000 e da temperatura. Pesquisa Agropecuária Brasileira 26: 1957-1968.

Wardle, D.A.; Nilsson, M.C.; Gallet, C. \& Zackrisson, O. 1998. An ecosystemlevel perspective of allelopathy. Biological Review 73: 305-319.

Weidenhamer, J.D.; Hartnett, D.C. \& Romeo, J.T. 1989. Density-dependent phytotoxicity: distinguishing resource competition and allelopathic interference in plants. Journal of Applied Ecology 26: 613-624.

Zar, J.H. 1999. Biostatistical analysis. Upper Saddle River, Prentice Hall.

Zhang, J.; Mao, Z.; Wang, L. \& Shu, H. 2007. Bioassay and identification of root exudates of three fruit tree species. Journal of Integrative Plant Biology 49: 257-261. 